\title{
A rare differential diagnosis of a groin lump: lymphangioma
}

\author{
Aswini Misro, Radhika Misro, Prakash Sapkota
}

Department of Surgery, Lumbini Medical College, Tansen, Nepal

\section{Correspondence to} Dr Aswini Misro, draswini@gmail.com

Accepted 25 March 2014

\section{DESCRIPTION}

A 56-year-old woman presented to the emergency department with worsening pain over a slow growing left groin swelling that started few weeks ago. The only other symptom was an episode of vomiting on the day of presentation. The patient had undergone a saphenous venous surgery few years ago. From venous disease point of view, she was asymptomatic since her surgery. There was no other notable history or family history. Clinical examination showed a $5 \times 6 \mathrm{~cm}$ swelling in the left groin, located below and lateral to the pubic tubercle (figure 1). Rest of the general and systemic examination was within normal limits. High-resolution soft tissue ultrasound scan of the groin could not rule out the possibility of an incarcerated groin hernia. Clinically, a diagnosis of incarcerated femoral hernia was made and the patient was taken for surgical exploration. Transinguinal surgical exploration

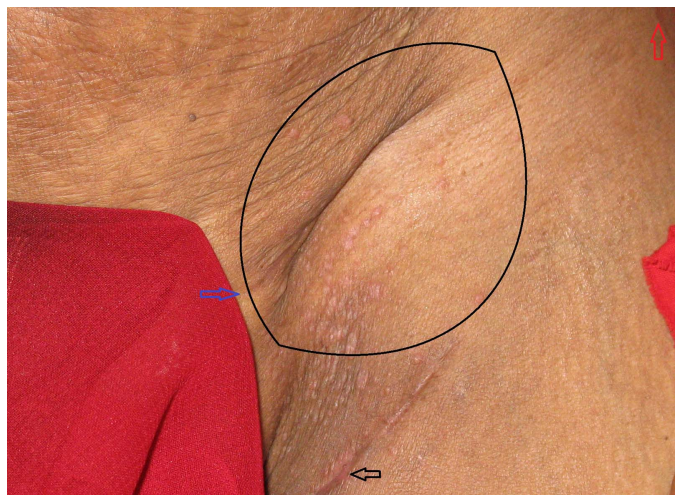

Figure 1 A swelling in the left groin located below and lateral to the pubic tubercle. The outline of the swelling has been demarcated. Blue arrow points to pubic tubercle. Red arrow points to the anterior superior iliac spine. Black arrow shows the scar of previous venous surgery.

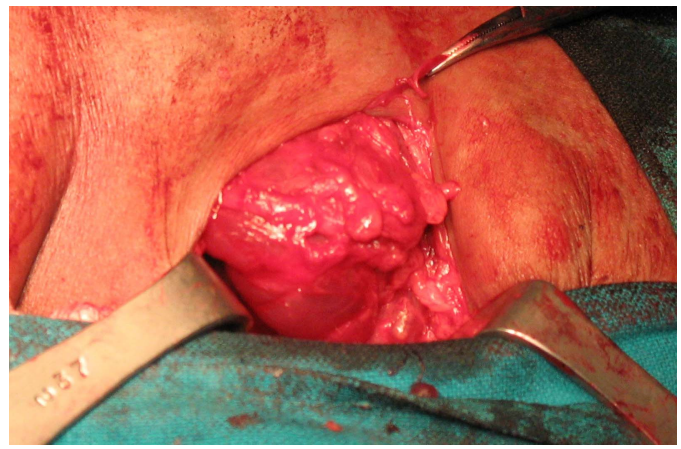

Figure 2 A lymphangioma being dissected from the groin. revealed several multilocular, semitranslucent cystic swellings of soft to firm consistency, ranging from 0.5 to $5 \mathrm{~cm}$, in the left femoral region consistent with lymphangioma (figures 2-5), which was later confirmed by histopathological examination.

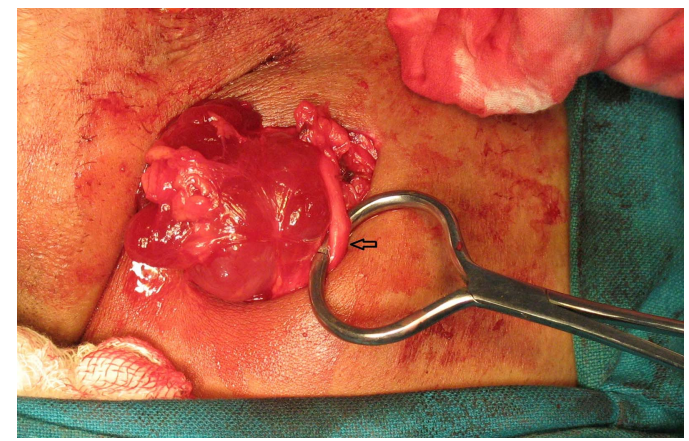

Figure 3 A multiloculated and semitranslucent cystic swelling is being dissected from the surrounding structures. The arrow shows the femoral nerve.

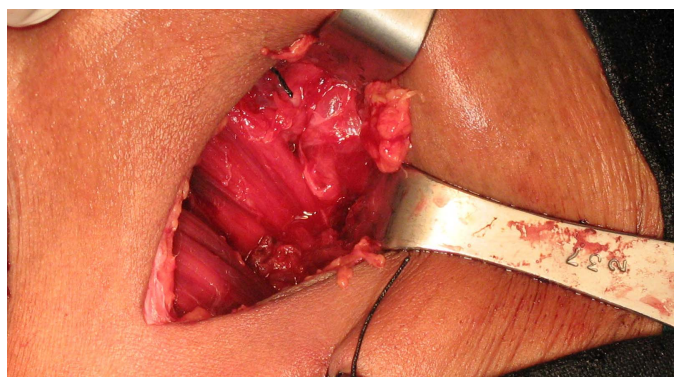

Figure 4 All the swellings have been excised.

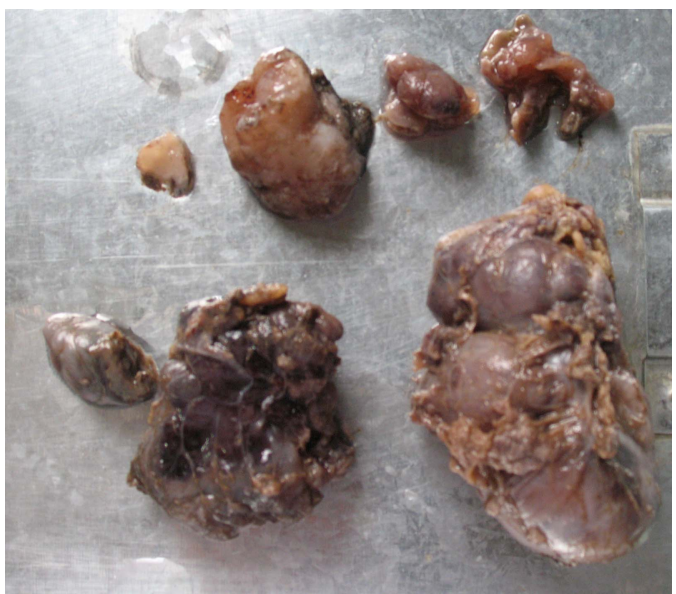

Figure 5 Multiple lymphangiomatous swellings ranging from 0.5 to $5 \mathrm{~cm}$. 


\section{Learning points}

- The differential diagnosis of groin lump may encompass a wide range of clinical entities. A clinician should consider all groin swellings to be hernias until proven otherwise. Although it is usually possible to reach a clinical diagnosis with careful history and examination, the possibility of such a rare differential diagnosis has to be kept in mind.

- Lymphangioma is a very uncommon congenital hamartomatous lymphoreticular malformation accounting for $4 \%$ of vascular tumours. It is commonly found in the neck, axilla, mediastinum, peritoneum, retroperitoneum and groin in early childhood. ${ }^{1-3}$

- Mainstay of treatment is complete excision, failing which recurrence is quite common.
Competing interests None.

Patient consent Obtained.

Provenance and peer review Not commissioned; externally peer reviewed.

\section{REFERENCES}

1 Kumar V, Fausto N, Abbus A. Robbins pathologic basis of disease. 7th edn. Philadelphia, PA: WB Saunders, 2005:498-9, 547.

2 Yasui T, Akita H, Sasaki S, et al. Cystic lymphangioma of retroperitoneum and groin. Urol Int 2000;64:115-17.

3 Puig S, Casati B, Staudenherz A, et al. Vascular low-flow malformations in children: current concepts for classification, diagnosis and therapy. Eur J Radiol 2005;53:35-45.

Copyright 2014 BMJ Publishing Group. All rights reserved. For permission to reuse any of this content visit http://group.bmj.com/group/rights-licensing/permissions.

BMJ Case Report Fellows may re-use this article for personal use and teaching without any further permission.

Become a Fellow of BMJ Case Reports today and you can:

- Submit as many cases as you like

- Enjoy fast sympathetic peer review and rapid publication of accepted articles

- Access all the published articles

- Re-use any of the published material for personal use and teaching without further permission

For information on Institutional Fellowships contact consortiasales@bmjgroup.com

Visit casereports.bmj.com for more articles like this and to become a Fellow 